\title{
Financial Determinants of Liquidity Positions of Listed Manufacturing Firms on the Nigerian Stock Exchange
}

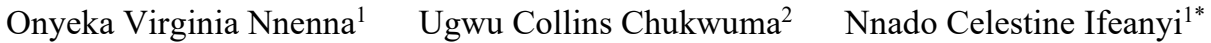 \\ 1.Department of Accountancy, Enugu State University of Science and Technology, Enugu, Nigeria \\ 2.Department of Accountancy, Federal University, Wukari, Nigeria
}

\begin{abstract}
The study evaluated the influence of financial determinants on cash holdings of selected quoted manufacturing firms in Nigeria. Specifically, the effect of these determinants (return on assets, financial leverage, dividend payment, cash flow volatility and market to book ratios) on cash holdings was examined. Influence of other determinants used in extant literature designated control variables in this instance was also investigated. Ex-postfacto research approach via quantitative panel methodology was employed to ascertain the effect of the predictors on corporate cash holdings. Data were collated from the audited annual reports of forty-one (41) firms for the thirteen year period: 2006-2018. Diagnostic tests confirmed the consistency and suitability of the Fixed Effects (FE) panel regression models. In other words, data were analyzed by means of Prais-Winsten Regression Correlated Panels Corrected Standard Errors (PCSEs). Findings indicate the existence of a significant positive influence of cash flow volatility, net working capital, market to book ratio on corporate cash holdings, but a significant negative effect of dividend payment and return on assets on cash and cash equivalents. These results imply that stockpiling cash and liquid assets substitutes decreases the value of the firm through market capitalization as they move in opposite direction. Further, highly levered firms may be operating sub-optimally given that the lingering local recession has made borrowing too expensive if not impossible. The study surmised that cash holdings of Nigerian manufacturing firms is significantly influenced by cash flow dynamics and availability of both liquid asset substitutes, market value of the firm and profitability. The study recommends that these firms maintain adequate cash budget and cash flow planning to ensure smooth running of operations, sufficient liquid and near liquid resources to cover maturing loans / debentures, and opt for an optimal liquidity profitability trade-off at least in the short run given that it boosts the magnitude of both liquidity and profitability. Keywords: Financial Determinants, Cash Holding, Firm Size.
\end{abstract}

DOI: $10.7176 / \mathrm{EJBM} / 12-14-06$

Publication date:May $31^{\text {st }} 2020$

\section{Introduction}

\subsection{Background of the Study}

Why do firms hold cash? Recent studies suggest that besides minimizing transactive, precautionary and agency costs, financial crises had altered firm characteristics and business environment as regards cash position. In fact, firms' cash balance in the financial statements has steadily increased over the years and it is a major concern for shareholders given that it worsened the agency problem (Xiao and Zhao, 2012). Global financial crisis (GFC) of 2008-2009 that had worldwide effect (Asia, Australia, Europe, Americas and Africa) necessitated a critical reassessment of the illiquidity problem. This became necessary given that the GFC was caused by firms' inability to maintain adequate liquidity. Optimizing profits involves pushing the total cost curve downwards until it reaches a minimum point as recession and other factors have restricted the upward movement of total revenue curve. The origin of cash levels and influence of cash holdings on value and performance of firms is still ambiguous as evidenced by divergent empirical results. Also, the relationship between cash balance and other sources of finance for the firms is not clear. Further, opportunity cost of holding excessive cash by managers, cost of cash stock out (fire brigade overdraft facilities) and so on are minimized by firms with sound financial flexibility (Adetifa, 2005; Borici and Kruja, 2016). The demise of 820 manufacturing firms in Nigeria between 2000 and 2009 is not dissociated from illiquidity and other factors (Kwode, 2015; Omolara and Asaleye, 2016).

As a result of the GFC and credit crunch, liquidity constraints influenced the cash holding policies and practices of firms such that these firms either stockpile excessive cash and near liquid resources, minimize cash outflows and / or contract exorbitant debt covenants (Chen, 2016; Borici and Kruja, 2016). Extant studies opine that cash holdings of firms are influenced by leverage ratio, return on assets, return on equity, investment opportunities, cash flow variability, dividend payments, net working capital, profit for the year, liquidity, free float, firm size, long and short term debt, investment in capital expenditures, tax expenses, age of firm, cash conversion cycle, corporate governance, internationalization of firm and industry (; Kariuki, Namusonge and Orwa, 2015; Hofmann, 2006; Harford, Mansi and Maxwell, 2008; Anjum and Malik, 2013; Isshaq and Bokpin, 2009; Hemmati, Rezaei and Anaraki, 2013; Magerakis, 2015; Le, Tran, Ta and Vu, 2018 ).

An optimal cash position involves having enough liquid and near-liquid resources to offset maturing debt obligations and current liabilities. Most recent studies incorporating quantitative panel methodology focused on 
firm specific factors rather than external factors exerting significant influence on cash positions of firms. These studies exhibited divergent views. That is, it is unclear as to which specific factors affect cash holdings of firms. Nonetheless, determining an optimal cash position for the firm entails management of the aforementioned factors adequately and at minimal cost. Use of cash flow analysis, cash budgets and liquidity ratios ensures necessary adjustments are made by the firm in this post GFC era to avoid illiquidity (Mizen, 2008; Abushammala and Sulaiman, 2014). Emphasis is on firm specific factors employing theoretical approach to ascertaining the determinants of corporate cash holdings (Opler, Pinkowitz, Stulz and Williamson, 1999) rather than on monetarist approach (Baumol, 1952; Miller and Orr, 1966). Uremadu, Egbide and Enyi (2012) contended that net cash flow ratio facilitates forecast of cash deficit and / or surplus in advance geared towards optimizing the balance of cash and cash equivalents.

\subsection{Statement of the Problem}

The threat to the survival of listed manufacturing firms in the form of incessant cash stockout has culminated in the drastic reduction from 1926 firms in 2000 to a mere 98 firms as at third quarter of 2016 (NSE, 2016). Manufacturers Association of Nigeria (MAN) and various chambers of commerce including the Lagos Chamber of Commerce and Industry (LCCI) have lamented the tough operating environment faced by their surviving members. Non-financial firms in Nigeria are characterized by recurring decline in profitability. It has been shown that developing economics are characterized by poor developed markets and financial sectors with practically no alternative sources of finance (Ge and Qui, 2007). The manufacturing industry was facilitated by the federal government to accelerate the growth of the economy through industrialization. It is feeble and heavily import dependent as it eats up more than $60 \%$ of our hard earned foreign exchange (Omotola, 2016). It has also failed the economy being characterized by capital flight, low capacity utilization, low economic value added, high production cost, borrowed technological base, etc. (Simon-Oke and Aribisala, 2010; Ozigbo, 2018).

Further, a priori studies on how firm-specific factors affect cash positions of firms have shown conflicting outcomes in these periods of increasing liquidity problems (Prenker and Kuck, 2009). Though manufacturing firms have internal control mechanisms (including effective corporate governance, share blocks, board of directors, presence of non-executive directors and institutional investors) to check the excesses of managers and controlling shareholders, the number of manufacturing firms in Nigeria has continued to dwindle.

While Trade-Off theory posits an existence of optimal cash balances for firms in perfect markets, it does not hold for firms operating in underdeveloped and imperfect markets: characteristics of developing countries including Nigeria. These firms must apply the Financial Hierarchy (Pecking Order) theory and / or the free Cash Flow Hypothesis (Agency theory) to survive. Regrettably, there exist no significant relationship between cash flow and cash holding of Nigerian quoted firms (Ogundipe, Salawu and Ogundipe, 2012) depicting that local managers adopt adhoc approaches in management of liquid resources. Meanwhile, Ogundipe et al (2012) investigated the determinants of corporate cash holdings in publicly listed Nigerian companies excluding only the financial sector for the study period (1995-2009) which was limited to the credit crunch period (2007-2009). Other relevant studies are comparative studies on several countries carried out by foreign authors. There were no other direct studies except Ogundipe et al (2012). This study became necessary as it extended the study period to 2018, employed different approach and emphasized manufacturing companies quoted on the Nigerian Stock Exchange.

The primary objective of the study is to ascertain the financial factors exerting significant influence on cash holdings of quoted manufacturing firms in Nigeria. Thus, the study strived to identify the extent of the influence of financial constraints (cash flow volatility), payment of dividends, net working capital, profitability, firm size, financial leverage, operating efficiency, investment opportunities and bank relationships on cash positions of Nigerian manufacturing firms.

\section{Literature Review \\ 2.1 Conceptual Review}

For the accountants, profit is the excess of total revenue over total expenses. Conversely, profitability denotes the capacity to earn profits by the firm or a given investment. That is, profitability refers to the relationship between the profits generated by the company and the investments that gave rise to these profits (Alshatti, 2015). There are contradictory theoretical predictions on the effects of profitability on the cash position of firms. Trade-off theory suggests that more profitable firms are less exposed to bankruptcy, possessing a greater incentive to take on debt in order to benefit from company debt tax savings (Jensen, 1986; Frank and Goyal, 2003). Extant literature proposes that profitability can have either a positive or negative effect on cash holdings. It is probably because profitable companies retain their profits within the firm, thereby accumulating cash over time.

Leverage, simply, is the ratio of total liabilities to total asset. It is also expressed as a percentage of share capital (i.e. gearing level). While operating leverage accentuated the influence of earnings volatility before corporate taxes and interests given significant movement on total revenue, financial leverage, conversely, is concerned with the measurement of both fixed capital and interest expenses of the firm (Khedkar, 2015). Further, 
pecking order theory posits positive relationship between leverage and cash holding, both trade-off and cash flow theories predict negative association between cash holding and leverage. Dividend Payment reduces cash holdings directly as payouts are cash outflows to the firm. The higher the dividends are, the less cash is available to stockpile. Conversely, dividend payout is negatively correlated with cash holdings given that a firm that pays cash dividend can easily raise additional funds by cutting the same dividend (Opler et al., 1999; Subramaniam, Tang, Yue and Zhou, 2011; Gao, Harford and Li (2013). By paying cash dividends, the firm acts on behalf of its shareholders (specifically, ageing shareholders) depicting minimal or decreasing agency problems.

Cash Flows refer to the firm's capacity to honor its debt covenants as they fall due using cash generated from operations. Cash flow indicators, while assessing internal financial potential of the firm, depict warning signs of potential credit problems (Brealey, Myers \& Marcus, 2007). Cash flow is one of most important factors influencing corporate cash holdings of firms. Growth / Investment Opportunities are difficult to measure directly. This gave rise to the use of many proxies: market-to-book ratio to measure long-term growth opportunities; sales growth to measure short-term growth opportunities; and research and development (R\&D) expenses to measure growth potential. Agency theory postulates the existence of a negative relationship between growth opportunities and leverage. To ensure these opportunities are not lost, firms do hold buffer liquid assets finance available and viable investment opportunities. Thus, firms with more or better growth opportunities do exhibit higher cash balances (Brealey, Myers, \& Allen, 2013).

Liquidity may measure Net Working Capital. It is net working capital scaled by total assets. It is the degree to which an asset or security can be bought or sold in the market without affecting the asset's price. A firm being in possession of lots of liquid assets other than cash has no need for large cash reserves. That is, when substitutes for cash are adequate, the need for cash holdings is drastically reduced. Opler et al (1999), Ferreira \& Vilela, (2004) \& Ozkan \& Ozkan (2004) all observed a negative relation of liquidity and cash holding with argument that firm can satisfy its precautionary and transactional needs with liquid asset and it can act as proxy for cash. Firm size may be described as either natural $\log$ of turnover or natural log of total asset. While trade-off theory of cash holding proposed negative relation between cash holding and firm size, the other two theories (pecking order theory and free cash flow theory) suggest a positive relationship between cash holding and firm size.

Extant literature including Guizani (2017), Le, Tran, Ta and Vu (2018) and Mohd-Ashhari and Faizal (2018) portrayed one of the key variables that affects cash holdings as firm size given that small firms exhibit higher information asymmetries than large firms, which makes external financing much more costly. Capital expenditures characterize cash outflows to the manufacturing firms. Firms that incur large capital expenditures, otherwise, large investments may experience increased future growth; particularly as regards investments in R\&D. this implies that all other investments are just costs to the firm. Empirical evidence suggests that firms stockpile cash but not to fund capital expenditures (Couderc, 2005; Subramaniam, et al, 2011; Gao et al., 2013).

\subsection{Empirical Reviews}

Sookim, Mauer and Sherman (1999) studied the determinants of corporate liquidity. The study employed a sample of 915 US non - financial firms which was drawn using purposive sampling technique. Data were analyzed using multivariate correlation and regression analyses. The independent / predictor variables of the study consist of growth prospects, leverage ratio, average cash conversion cycle, bankruptcy predictor, size of the firm and cash flow adequacy. The study stated that increasing variability of projected cash flows, costs of external finance, and profits realizable from available investment opportunities do optimize liquidity investment until the slope of the curves reaches a maximum (turning) point. Ogundipe, Salawu and Ogundipe (2012) opined that the determinants of corporate cash holdings in Nigeria should include inventories, accounts receivables, growth opportunities, leverage and financial distress. The study used a sample of 54 non - financial firms listed in Nigeria Stock Exchange (NSE) for 15 year period (1995-2009). These firms were selected using purposive sampling method. Data collated from the audited annual financial statements of these firms were analyzed using generalized methods of moments (GMM) of dynamic panel methodology. However, dynamic panel estimation has inherent limitations when analyzing snapshot data extracted from audited annual financial statements.

In their study, Manyo and Ogakwu (2013) explored the influence of liquidity on return on assets of forty six (46) quoted firms listed on the Nigerian Stock Exchange for the ten year period (2000 - 2009). Utilizing ex post facto approach as regards collated data, they used multiple regressions to assess the relationship between liquidity, the independent variable against return on assets. The results affirmed the existence of a significant positive relationship between the regressor and the regressand. Return on assets is influenced positively by liquidity at a marginal rate of $2.8 \%$. In addition, there is a significant positive influence of leverage (excluding other control variables) on growth and return on assets. Jamil, Anwar, Afzaal, Tariq and Asif (2016) carried out a study on the key firm specific factors exerting significant influence on the cash holdings of fifty (50) firms quoted at the Karachi Stock Exchange for the three year period (2012-2014). Analyses of data were carried out using the ordinary least squares regressions on the processed data (information). These results are in alignment with some previous empirical results: Afza and Adnan (2007), Gill and Shah (2012) and Ogundipe, Salawu and Ogundipe 
(2012). The study showcased a positive relationship between cash holdings and the predictor variables (investment, net working capital, firm size and board size). The dependent variable is, of course, negatively influenced by such predictor variables as leverage, return on assets and debt structure.

Aoyagi and Ganelli (2014) investigated annual panel data of 3,412 nonfinancial (including manufacturing firms) Japanese firms for a period of four years (2000-2003). Employing panel least squares, the study avowed that better corporate governance is linked to lower ratios of cash to market value of the firm (market capitalization). The study opined that enhancing a Japanese firm's corporate governance score from the local average of 39 percent to the G7 average of 49 percent is most likely to decrease the cash-to-market capitalization ratio from an average of 45 percent to approximately 42 percent. The study asserted that the effect might be stronger if corporate governance is enhanced beyond the G7 average given that the second-round effects of governance reforms are put into consideration.

Aftab, Javid, and Akhter (2018) critically examined the determinants of cash holdings of multinational companies and other regional firms on a global scale. The study touched all the continents by using a sample of 5,957 firms drawn strategically from 47 countries for the ten year study period (2007-2016). Employing panel generalized method of moments (PGMM), the study posited that market to book ratio, leverage, dividend, intangibles, profitability and net working capital exerted strong negative influence on cash holdings while actual investments, cash flows, firm size and financial strength affected cash holdings of these firms positively and significantly. Thi, Nhan and Ha (2016) investigated the relationship between cash holdings and the value of the firm of 650 quoted Vietnamese companies for the eight year period (2008-2015). Employing panel least squares, the results revealed a strong inverse relationship between dependent and explanatory variables (including control variables); an insignificant positive association between state ownership and the value of the firm.

Kruja and Borici (2016) considered the determining factors responsible for varied levels of cash balance of firm in the Shkodra region. The study population is made up of all firms in the region excluding banks and other financial institutions. Thirty firms were purposely drawn and their annual reports for a two year period (20132014) collated and analyzed using ordinary least square regression and ANOVA. The findings showed that cash holdings of firms are significantly and positively affected by net working capital, total debt including bank borrowings, profitability and firm size. In their study of the factors influencing the levels of cash and cash equivalents held by 235 quoted non-financial firms drawn from 23 developed and developing countries, Rafinda, Hadzhiev, Tähkänen.and Helvert (2018) used panel regressions framework to arrive at inconclusive evidence with respect to unexpected signs of coefficients.

Shabbir, Hashmi, and Chaudhary (2016) empirically identified the firm specific factors affecting the level of cash holdings of 150 firms quoted on the Karachi Stock Exchange of Pakistani. Banks and other financial institutions were excluded given that these firms possess a different capital structure in comparison to non-financial firms. The study period was nine years $(2004-2012)$. Collated data were analyzed using Pearson correlations and multiple regression and eight hypotheses tested using the analysis of variance (ANOVA). The results showed that cash holdings $(\mathrm{CH})$ of Pakistani non-financial firms is positively and significantly influenced by cash flow volatility, market-to-book ratio, profitability and firm size. However, $\mathrm{CH}$ is negatively and significantly influenced by leverage, liquidity and debt maturity (at $\alpha=0.10$ ).

Mohd-Ashhari and Faizal (2018) looked into the internal factors affecting the level and quality of cash positions of 100 small and medium enterprises (SMEs) in Malaysia for the relevant period of six years (2011 2016). Employing exogenous variables similarly used in extant literature such as leverage, growth opportunities, firm size, firm age, cash flow volatility, capital expenditure, net working capital and return on assets, the study via panel least squares and post estimation diagnostics indicated that all these explanatory variables are significant determinants of the regressand. Umrya and Diantimala (2018) explored the factors responsible for the level of cash and cash equivalents held by 106 quoted Indonesian firms for the relevant period of six years (2012-2017). Adopting multiple regressions, the study showcased that debt maturity is negatively related to cash holdings of these sampled firms while financial distress relationship with the dependent variable is positive and significant

Enow and Isaacs (2018) investigated the causative factors that influence dividend payments to shareholders in South Africa. The study emphasized ten (10) financial firms quoted on their stock exchange for the five year period (2012-2016). Using multivariate analyses, it was observed that upward movement in dividend payment is synonymous with significant increases in return on asset, return on equity and earnings per share (EPS) of the sampled firms. However, Anton (2016) examined the influence of dividend policies on the value of the firm. The study employed panel methodology, in particular, fixed effect statistics and discovered that the value of the firm is directly and significantly affected by dividend payout ratio, firm size and leverage. Their study aligned to some of the findings of Guizani (2017).

\subsection{Theoretical Framework}

The study is anchored on the Financial Hierarchy (Pecking Order) Theory (Myers, 1984) and the Free Cash Flow Hypothesis (Jensen, 1986) with respect to working capital financing and investing policies. According to Pecking 
Order Theory, firms have a preferred hierarchy for financing decisions. The finance manager in a bid to exercise more control of the company and reduce agency cost of equity most prefer to use internal financing (retained earnings including depreciation in reality exist first in cash form only if cash basis is employed; otherwise, in cash and accounts receivables form if accrual basis is used) before resorting to any form of external financing as internal funds incur no flotation costs and require no additional disclosure of proprietary financial information. The manager, thus, avoids severe market discipline and a possible loss of competitive advantage resulting from issue of either new debt or new equity. The key assumption of the theory is asymmetric information, or the likelihood that a firm's managers know more about the company's current earnings and future growth opportunities than do outside investors. That is, financial managers possess insider information unavailable to outsiders and they desire to keep such information proprietary. The second key assumption is that managers will act in the best interests of the company's existing shareholders (Myers \& Majluf, 1984). Further, adequate net working capital ensures that managers pursue viable projects (positive NPV projects) relieved of being forced to issue junk debts and / or undervalued securities (Wasiuzaman and Arumugam, 2013).

According to Jensen's Free Cash Flow Hypothesis, managers accumulate cash and cash equivalents so as to broaden their control network with respect to investments in assets (Ferreira and Vilela, 2004). That is, finance managers are most likely to hoard cash and cash equivalents targeted towards minimizing the firm's investment risk. Hence, the surplus net working capital enables the manager's pursuit of goals that may be at odds with goals of the shareholders. This aligns with the fact that managers would retain cash and close liquid substitutes at all cost and pay stipends to the shareholders (Drobetz, Gruninger and Hirschvogl, 2010). Moreover, the managers may be hoarding cash and its equivalents to prevent hostile takeovers by business vultures that purchase a firm for its breakup value wherein the later is higher than the market value of the firm (Opler, Pinkowitz, Stulz and Williamson, 1999).

\section{Methodology}

The study employed ex-post facto research design. Secondary data were collated from the sampled 41 manufacturing firms' audited annual reports for the 13 years (2006-2018). The relationships between the variables studied in lieu of the manufacturing firms were tested using adjusted Fixed Effects Panel Least Squares Regression (Prais-Winsten Regression Correlated Panels Corrected Standard Errors) after carrying out diagnostics for stationarity and cointegration. The regressand is proxied by cash and cash equivalents (CASH), while the independent variables are made up of financial leverage (LEV) and natural logarithm of total assets (LnTA). The control variables include net working capital (NWC), cash flow (CF) and sales growth (SG). The equation becomes $\mathrm{CASH}_{\mathrm{it}}=\beta_{0}+\beta_{1} \mathrm{ROA}_{\mathrm{it}}+\beta_{2} \mathrm{LEV}_{\mathrm{it}}+\beta_{3} \mathrm{DIVP}_{\mathrm{it}}+\beta_{4} \mathrm{CFV}_{\mathrm{it}}+\beta_{5} \mathrm{MKTB}_{\mathrm{it}}+\mathrm{c}_{\mathrm{it}}+\varepsilon_{\mathrm{it}}$

With the control variables introduced, the regression equation becomes

$$
\mathrm{CASH}_{\text {it }}=\beta_{0}+\beta_{1} \mathrm{ROA}_{\text {it }}+\beta_{2} \mathrm{LEV}_{\text {it }}+\beta_{3} \mathrm{DIVP}_{\text {it }}+\beta_{4} \mathrm{CFV}_{\mathrm{it}}+\beta_{5} \mathrm{MKTB}_{\mathrm{it}}+\beta_{6} \mathrm{LnTA}+\beta_{7} \mathrm{NWC}_{\text {it }}
$$

$$
+\beta_{8} \mathrm{CF}_{\mathrm{it}}+\beta_{9} \mathrm{SG}_{\mathrm{it}}+\mathrm{c}_{\mathrm{it}}+\varepsilon_{\mathrm{it}}
$$

Where CASH $=$ Cash and Cash Equivalents / (Total Assets - Cash and Cash Equivalents)

Cash Flow = Net Cash Flows from Operations / Current Liabilities

Cash flow volatility $=\mathrm{CFV}=\mathrm{As}$ a proxy for the volatility of cash flows the standard deviation of cash flows over the sample period (13 years) is divided by total assets to linearize the deviations.

$\mathrm{DIVP}=$ Dividend Paid $/$ Total Assets $\quad$ Div Paid $=\mathrm{P}=1$ Div Unpaid $=\mathrm{NP}=0$

Working Capital $=\mathrm{CA}-\mathrm{CL}$

NWC $=$ Net Working Capital $=($ Working Capital - Cash and Cash Equivalent $) /$ Total Assets

LEV measures the Financial Leverage as ratio of Total Debt to Total Asset for firm $\mathrm{i}$ in the year $\mathrm{t}$

Total Debt $=\mathrm{TA}-\mathrm{BVE}$ or TD $=\mathrm{STD}+\mathrm{LTD}$

$\mathrm{ROA}=$ (Profit for the Year) $/$ (Net Assets)

MKTB = Market-To-Book ratio $=($ Market Value of Equity + Book Value of Debt $) /$ Total Assets

Market Value of Equity = Market Capitalization as at 31 December of the relevant years

$\beta_{0}$ is the constant term or intercept for firm i in the year t. $\beta_{1}, \beta_{2}, \beta_{3}, \beta_{4}, \beta_{5}$, and $\beta_{6}$, are linear regression coefficients to be estimated.

$\mathrm{c}_{\mathrm{it}}$ is the non-observable individual effect while $\varepsilon_{\mathrm{it}}$ is the disturbance or error term for firm $\mathrm{i}$ in the year $\mathrm{t}$. LnTA $=$ Natural Logarithm of Total Assets used as proxy for size

Sales Growth $=\mathrm{SG}=\left(\right.$ Sales $_{\mathrm{t}}-$ Sales $\left._{\mathrm{t}-1}\right) /$ Sales $_{\mathrm{t}-1}$

Note that the common variables employed in the literature are used as control variables. 


\section{Results}

Table 1: Descriptive Statistics

\begin{tabular}{|c|c|c|c|c|c|c|c|c|}
\hline \multirow[t]{2}{*}{ Var. } & \multirow[t]{2}{*}{ Obs. } & \multirow[t]{2}{*}{ Mean } & \multirow[t]{2}{*}{ Standard } & \multirow[t]{2}{*}{ Standard } & \multirow{2}{*}{$\begin{array}{c}\text { Prob. } \\
\text { Deviation }\end{array}$} & Prob. & Min & \multirow[t]{2}{*}{ Max } \\
\hline & & & & & & Skewness & Kurtosis & \\
\hline $\mathrm{ROA}$ & 507 & 0.2523 & 0.6384 & 0.0284 & 0.0000 & 0.0000 & -1.0963 & 7.8495 \\
\hline LEV & 507 & 0.5021 & 2.8405 & 0.1262 & 0.0000 & 0.0000 & -6.7285 & 55.9322 \\
\hline DIVP & 507 & 0.6588 & 0.4746 & 0.0211 & 0.0000 & 0.0000 & 0.0000 & 1.0000 \\
\hline CFV & 507 & -0.0082 & 0.3025 & 0.0134 & 0.0000 & 0.0000 & -5.6518 & 0.6697 \\
\hline MKTB & 507 & 0.6925 & 0.4784 & 0.0213 & 0.0000 & 0.0000 & -2.3785 & 3.0286 \\
\hline $\mathrm{CASH}$ & 507 & 0.1525 & 0.3321 & 0.0146 & 0.0000 & 0.0000 & -0.1615 & 6.9244 \\
\hline CFL & 507 & 0.1961 & 0.5923 & 0.0263 & 0.0000 & 0.0000 & -3.2774 & 2.0146 \\
\hline NWC & 507 & 1.2199 & 0.6317 & 0.0281 & 0.0000 & 0.0000 & -0.9541 & 3.8113 \\
\hline LnTA & 507 & 15.7147 & 2.3909 & 0.1062 & 0.0000 & 0.0000 & 0.0008 & 20.6937 \\
\hline SG & 507 & 0.3246 & 3.0851 & 0.1370 & 0.0000 & 0.0000 & -7.0825 & 67.8623 \\
\hline
\end{tabular}

Source: Authors' STATA 13 Outputs

Table 2: Correlation Matrix with P-values involving 507 Observations

\begin{tabular}{|c|c|c|c|c|c|c|c|c|c|}
\hline \multirow{2}{*}{\multicolumn{10}{|c|}{$\begin{array}{l}\text { CASH CFL } \\
\text { CASH } 1.0000\end{array}$}} \\
\hline & & & & & & & & & \\
\hline \multirow[t]{2}{*}{$\mathrm{CFL}$} & $0.1247^{*}$ & 1.0000 & & & & & & & \\
\hline & 0.0049 & & & & & & & & \\
\hline \multirow[t]{2}{*}{ NWC } & $0.0968^{*}$ & $0.1653^{*}$ & 1.0000 & & & & & & \\
\hline & 0.0294 & 0.0002 & & & & & & & \\
\hline \multirow[t]{2}{*}{ LEV } & -0.0149 & 0.0197 & -0.0398 & 1.0000 & & & & & \\
\hline & 0.7378 & 0.6589 & 0.3713 & & & & & & \\
\hline \multirow[t]{2}{*}{ ROA } & -0.0351 & $0.0953^{*}$ & 0.0296 & 0.0412 & 1.0000 & & & & \\
\hline & 0.4307 & 0.0320 & 0.5060 & 0.3547 & & & & & \\
\hline \multirow[t]{2}{*}{ MKTE } & B $0.1410^{*}$ & $0.2155^{*}$ & $0.7078^{*}$ & 0.0061 & 0.0274 & 1.0000 & & & \\
\hline & 0.0015 & 0.0000 & 0.0000 & 0.8903 & 0.5385 & & & & \\
\hline \multirow[t]{2}{*}{ CFV } & 0.0314 & $0.1133^{*}$ & $0.0925^{*}$ & 0.0356 & $-0.3088^{*}$ & 0.0399 & 1.0000 & & \\
\hline & 0.4805 & 0.0107 & 0.0373 & 0.4237 & 0.0000 & 0.3694 & & & \\
\hline \multirow[t]{2}{*}{ LNTA } & 0.0497 & -0.0459 & 0.0480 & $-0.1347^{*}$ & $-0.3192^{*}$ & 0.0806 & $-0.0948^{*}$ & 1.0000 & \\
\hline & 0.2643 & 0.3021 & 0.2805 & 0.0024 & 0.0000 & 0.0699 & 0.0328 & & \\
\hline \multirow[t]{2}{*}{ SG } & 0.0504 & -0.0068 & 0.0047 & 0.0097 & -0.0106 & -0.0061 & 0.0243 & -0.0541 & 1.0000 \\
\hline & 0.2571 & 0.8778 & 0.9163 & 0.8280 & 0.8113 & 0.8902 & 0.5851 & 0.2237 & \\
\hline \multirow[t]{2}{*}{ DIVP } & $-0.0935^{*}$ & 0.0389 & -0.0019 & 0.0506 & 0.0031 & 0.0249 & 0.0834 & $-0.1757^{*}$ & 0.0346 \\
\hline & 0.0352 & 0.3817 & 0.9662 & 0.2556 & 0.9446 & 0.5763 & 0.0605 & 0.0001 & 0.4372 \\
\hline
\end{tabular}

Source: Authors' STATA 13 Outputs

Table 3: Prais-Winsten Regression Correlated Panels Corrected Standard Errors

\begin{tabular}{lcccccc}
\hline CASH & Coef. & $\begin{array}{c}\text { Semirobust } \\
\text { Std. Err. }\end{array}$ & $\mathrm{t}$ & $\mathrm{P}>|\mathrm{t}|$ & [95\% Conf. & Interval] \\
\hline ROA & .0025905 & .0084807 & 0.31 & 0.760 & -.0140719 & .0192529 \\
LEV & -.000338 & .0016849 & -0.20 & 0.841 & -.0036483 & .0029726 \\
DIVP & -.0261927 & .0101721 & -2.57 & 0.010 & -.0461777 & -.0062063 \\
MKTB & .1323356 & .0142272 & 9.30 & 0.000 & .1043827 & .1602885 \\
CFL & .0261984 & .0082981 & 3.16 & 0.002 & .0098947 & .0425021 \\
NWC & -.027452 & .0106841 & -2.57 & 0.010 & -.0484435 & -.0064605 \\
CFV & .0344326 & .0171494 & 2.01 & 0.045 & .0007383 & .0681268 \\
LnTA & .0074404 & .0021996 & 3.38 & 0.001 & .0031188 & .0117622 \\
SG & .0064435 & .0015362 & 4.19 & 0.000 & .0034252 & .0094618 \\
CONS & -.0490129 & .0378664 & -1.29 & 0.196 & -.1234109 & .0235385 \\
rho & .7936818 & & & & number of obs $=507$ \\
Durbin-Watson (original) & 1.900483 & $\mathrm{~F}(9,497)=21.71$ & Prob $>\mathrm{F}=0.0000$ \\
Durbin-Watson (transformed) & 2.001791 & $\mathrm{R}-\mathrm{squared}=0.4045$ & Root MSE $=0.3272$ \\
\hline
\end{tabular}

Source: Authors' STATA 13 Outputs 
Regression Equation for the Comprehensive Model

$\mathrm{CASH}=-.049+.003 \mathrm{ROA}+.0003 \mathrm{LEV}-.026 \mathrm{DIVP}+.034 \mathrm{CFV}+.132 \mathrm{MKTB}+.0074 \mathrm{LnTA}+.006 \mathrm{SG}+.026 \mathrm{CFL}$ $-.027 \mathrm{NWC}$

\section{Discussions}

The compiled figures for both the dependent and explanatory variables are pooled and averaged to arrive at the values portrayed on table 1 above. In other words, the means of the ten variables, a powerful median measure even though vulnerable to extreme values, of the quoted forty - one manufacturing firms in 507 observations are depicted above. These sample means are expected to approximate the true population means of manufacturing firms in Nigeria. On the other hand, the standard deviation, a measure of dispersion, is quite large in comparison to the respective means which is expected as the sampled firms come from the diverse ninety - five subsectors. This is characteristic of heterogeneous (panel) data. The largeness is quite obvious given that the mean, standard deviation and standard error do exist in the same metrics. Opportunely, the standard errors of the means of variables, most valuable estimator, are quite small and aligned to the theoretical postulate of becoming smaller as the sample size approaches the population. Except for sales growth at $13.7 \%$, leverage ratio at $12.6 \%$ and logarithm of total assets at $10.6 \%$, the values of the remaining variables recorded standard error values less than 5\%. These three are not even statistically significant at $90 \%$ confidence interval.

Skewness is synonymous with the standardized third moment. It connotes a number describing only the asymmetry of the distribution about the sample mean. While negative kurtosis show flatness and light tails, positive kurtosis portrays peakedness and heavy tails in relation to the normal distribution. The probabilities of both moments in this case are below $5 \%$ for all the entered variables. In the same vein, the P-values accentuated the statistical significance of being normally distributed as the probabilities of both skewness and kurtosis exceeded that of Chi Square for all the entered variables.

The Pearson correlation coefficients measure the degree of association between the different variables. Probability of each correlation coefficient is beneath each. Further, the P-values that are less than 5\% show strong statistical significance. The table above portrays a negative influence of three predictors: leverage ratio, return on assets and dividend paid on cash and cash equivalents. Only dividend paid exerted a significant negative influence on the regressand. Further, the remaining explanatory variables (cash flow liquidity, net working capital, market to book ratio, cash flow variability, logarithm of total assets and sales growth) exerted positive influences on cash and cash equivalents. In this instance, only three predictors: cash flow liquidity, net working capital and market to book ratio exerted significant positive influence on the regressand.

There also exists significant positive relationship between cash flow liquidity, on the one hand, and net working capital, return on assets, market to book ratio and cash flow variability. Market to book ratio and cash flow variability is directly related to net working capital while logarithm of total assets is significantly and negatively related to both leverage ratio and return on assets. While return on assets is perfectly and negatively related to both cash flow variability and logarithm of total assets, market to book ratio exerted a perfect and direct relationship with net working capital and cash flow liquidity. Similarly, cash flow liquidity is perfectly and directly related to net working capital while dividend paid has a perfect and negative relation with logarithm of total assets. All these perfect relationships among predictor and control variables indicate evidence of colinearity (i.e. perfect association between explanatory variables. The latter is a characteristic of panel data which is ameliorated using colinearity diagnostics in so far as there are no lagged values and all dummies eradicated.

In table 3, the transformed Durbin-Watson d-statistic is perfect 2 (from 1.90 to 2.00) indicating that any serial correlation has been corrected. F - Statistic (a powerful statistic for testing hypothesis) depicts that the combined influence of all the explanatory variables including the control variables on cash holdings of firms is statistically significant. In other words, the entered explanatory variables exerted strong effect on cash positions of firms excluding leverage ratio and return on assets. The multiple coefficient of determination, R-squared, is $40.45 \%$ indicating that $40.5 \%$ movement on cash holdings of firms is caused by these determinants. Further, $40.5 \%$ is a significant influence. The $p$-value is perfect at 0.0000 which is lower than $\alpha=0.05$ corroborating that the influence of the explanatory variables is statistically relevant. Specifically, seven of the explanatory variables: cash flow liquidity, net working capital, market to book ratio, cash flow variability, logarithm of total assets, sales growth and dividend paid exerted strong influence on cash and cash equivalents.

In practical terms, a unit increase in cash flow liquidity and net working capital significantly increased cash holdings of the quoted firms by 0.026 units and -0.027 units respectively. Conversely, leverage ratio and return on assets increased albeit insignificantly the cash holdings of firms by -0.00034 units and 0.0026 units respectively. This is deducible from their high $\mathrm{P}$-values (leverage at $\mathrm{P}=0.841>0.05$ and return on assets at $\mathrm{p}=0.760$ ) and extremely low coefficients $(-0.00034$ and 0.0026$)$. However, market to book ratio, logarithm of total assets, cash flow liquidity and sales growth showcased perfect relationships with cash and cash equivalents when values are rounded to two decimal places. Their perfect P-values and high t-statistics in that order are [0.00, 9.30], [0.00, $3.38],[0.00,3.16]$ and $[0.00,4.19]$. With respect to values of the coefficient, for each unit increase of market to 
book ratio, logarithm of total assets, cash flow liquidity and sales growth, cash and cash equivalent is increased by 0.1323 units, 0.0074 units, 0.0262 units and 0.0064 units respectively. In addition, all the control variables (cash flow variability, logarithm of total assets, sales growth and dividend paid) exhibited strong relationships with cash holdings of firms.

\section{Conclusion}

The influence of some financial factors on cash holdings of manufacturing firms in Nigeria was investigated for the thirteen year period (2006 - 2018). The study employed panel least squares estimation technique and surmised that manufacturing firms with adequate liquid resources including near liquid assets perform much better in this era of recurring recession if cash and cash equivalents are used optimally. Results have shown that operational cash holdings of firms studied are tuned to liquidity slack theory and pecking order theory. The study posited that the magnitude of cash and cash equivalents is pertinent to the sampled firms if optimal liquidity - profitability trade-off is desired. However, the manufacturing firms in reality either stockpile enough cash or negotiate on time with their banks to avoid court induced liquidation by creditors and debenture holders. There exists limited evidence for the predictor variable: leverage ratio and this warrants further and comprehensive investigation. Meanwhile, all the control variables studied exerted significant influence on corporate cash holdings.

The findings signal that Nigerian manufacturing firms ought to forecast using cash budgets to facilitate maintenance of adequate cash flows for transactional / operational and other purposes as three of the financial determinants (i.e. cash flow liquidity / volatility, net working capital and market to book ratio) strongly influences corporate cash holdings positively. However, the cash and cash equivalents must be kept at optimal level given that return on assets, one of the stated determinants, influences corporate cash holdings significantly and negatively. In other words, operational cash management theories supports an optimal liquidity - profitability trade-off as decisions involving corporate cash holding are essential aspects of capital structure in the short run (Sohani, 2009). Notwithstanding that leverage exhibited insignificant negative influence on cash and cash equivalents, top management of firms must keep enough liquid resources to offset debenture / loan interests as they fall due as debenture holders possess the ability to liquidate these manufacturing firms if interests on their investments are not paid timely and fully. Further, reasons for carrying cash are ambiguous in that Soku (2011) argued financial flexibility as another reason for holding cash besides the transactive, precautionary and speculative motives.

\section{References}

Abushammala, S. M. \& Sulaiman, J. (2014). Impact of macroeconomic performance on corporate cash holdings: some evidences from Jordan. Asian Economic and Financial Review, 4 (10), 1363-1377.

Adetifa, S. B. (2005). Corporate finance and investment strategy ( $2^{\text {nd }}$ ed.). Lagos: CIBN Press Ltd. 426P.

Aftab, U., Javid, A. Y. \& Akhter, W. (2018). The determinants of cash holdings around different regions of the world. Business \& Economic Review, 10 (2), 151-182.

Afza, T., \& Adnan, S. M. (2007). Determinants of corporate cash holdings: A case study of Pakistan.

Akhavan, P., Shekarchizadeh, A., Abasaltian, A. \& Abasaltian, M. (2015). Studying the effective factors on holding cash funds in the organizations (a comparative study among different theories) Applied Mathematics in Engineering, Management and Technology 3 (2) 273-279.

Alshatti, A. S. (2015). The effect of the liquidity management on profitability in the Jordanian commercial banks. International Journal of Business and Management, 10 (1), 62 - 71.

Anjum, S., \& Malik, Q. A. (2013). Determinants of corporate liquidity-An analysis of cash holdings. Journal of Business and Management, 7 (2), 94-100.

Anton, S. G. (2016). The impact of dividend policy on firm value: A panel data analysis of Romanian listed firms. Journal of Public Administration, Finance and Law, 10, 107-112.

Aoyagi, C. and G. Ganelli, (2014). Unstash the cash! Corporate governance reform in Japan. IMF Working Paper, $14(140), 1-23$.

Baumol, W. J. (1952). The transactions demand for cash: An inventory theoretic approach. Quarterly Journal of Economics, 66 (4), $545-556$.

Borici, A. \& Kruja, A. (2016). Determinants of firm's cash holding: Evidence from Shkodra region, Albania. International Journal of Economics, Commerce and Management, 4 (4), 41-52.

Brealey, R. A., Myers, S. C. \& Allen, F., (2013). Principles of corporate finance ( $11^{\text {th }}$ ed.). New York: McGrawHill Irwin, 1296P

Brealey, R., Myers, S. \& Marcus, A. J. (2007). Fundamentals of corporate finance (5 ${ }^{\text {th }}$ ed.). New York: McGrawHill, 722P.

Chen, L. (2016). Corporate investments, cash flows and cash holdings: Evidence from the oil industry before and after the financial crisis. Accounting and Finance Research, 5 (4), 192-213.

Couderc, N. (2005). Corporate cash holdings: Financial determinants and corporate governance. Working paper, University of Paris. 
Drobetz, W., Grüninger, M. C., \& Hirschvogl, S. (2010). Information asymmetry and the value of cash. Journal of Banking \& Finance, 34 (9), 2168-2184.

Enow, S. T. \& Isaacs, E. B. H. (2018). Factors that determine dividend payout. evidence from the financial service sector in South Africa. Journal of Banking and Finance Management, 1 (1), 48-53.

Ferreira, M. A., \& Vilela, A. S. (2004). Why do firms hold cash? Evidence from EMU countries. European Financial Management, 10 (2), 295-319.

Frank, M. Z. \& Goyal, V. K. (2003). Testing the pecking order theory of capital structure. Journal of Financial Economics, 67, $217-248$.

Gao, H., Harford, J., \& Li, K. (2013). Determinants of corporate cash policy: Insights from private firms. Journal of Financial Economics, 109(3), 623-639.

Ge, Y. and Qui, J. (2007) Financial development, bank discrimination and trade credit, Journal of Banking and Finance, 31, 513-530.

Gill. A and Shah, C (2012): Determinants of corporate cash holdings: Evidence from Canada. International Journal of Economics and Finance, 4 (1),

Guizani, M. (2017). The financial determinants of corporate cash holdings in an oil rich country: Evidence from Kingdom of Saudi Arabia. Borsa Istanbul Review, 17(3), 133-143.

Harford, J., Mansi, S. A. \& Maxwell, W. F. (2008). Corporate governance and firm cash holdings in the US. Journal of Financial Economics, 87, 535-555.

Hemmati, H., Rezaei, F., \& Anaraki, N. B. (2013). Investigating the financial determinants of corporate cash holdings in Tehran stock exchange. Interdisciplinary Journal of Contemporary Research In Business, 5(6), 92-103.

Hofmann, P. (2006). Why New Zealand companies hold cash: An empirical analysis. Unpublished PhD Thesis.

Isshaq, Z. \& Bokpin, G. A. (2009). Corporate liquidity management of listed firms in Ghana. Asia- Pacific Journal of Business Administration, 1 (2), 189-198.

Jamil, S., Anwar, A., Afzaal, N., Tariq, A. \& Asif, M. (2016). Determinants of corporate cash holdings: Empirical analysis of Pakistani firms. IOSR Journal of Economics and Finance (IOSR-JEF), 7 (3-3), 29-35.

Jensen, M. C. (1986). Agency costs of free cash flow, corporate finance and takeovers. American Economic Review, $76(2), 323-329$.

Kariuki, S. N., Namusonge, G. S., \& Orwa, G. O. (2015). Determinants of corporate cash holdings: evidence from private manufacturing firms in Kenya. International Journal of Advanced Research in Management \& Social Sciences, 4(6), 15-33.

Khedkar, E. B. (2015). A study of leverage analysis and profitability for Dr Reddy's Laboratories. International Journal of Research in Engineering and Social Sciences, 5 (5), 17-31.

Kwode, I. E. (2015) Capital market and the performance of the manufacturing industries in Nigeria: 1970 - 2012. European Journal of Business and Management, 7 (13), 11 - 23.

Le, D. H., Tran, P. L., Ta, T. P., \& Vu, D. M. (2018). Determinants of corporate cash holding: Evidence from UK listed firms. Business and Economic Horizons, 14 (3), 561-569.

Magerakis, E. I. (2015). Cash holdings and firm characteristics: Evidence from UK market. An Unpublished MBA Thesis, University of Patras.

Manyo, T. K. and Ogakwu, V. N. (2013). Impact of liquidity on return on assets of firms: Evidence from Nigeria. International Journal of Management and Information Technology, 6 (3), 885 - 894.

Miller, M. H., \& Orr, D. (1966). A model of the demand for money by firms. Quarterly Journal of Economics, 80 (3), 413-435.

Mizen, P. (2008). The credit crunch of 2007-2008: A discussion of the background, market reactions, and policy responses. Federal Reserve Bank of St. Louis Review, 90 (5), 531-567.

Mohd-Ashhari, Z. \& Faizal, D. R. (2018). Determinants and performance of cash holding: Evidence from small business in Malaysia. International Journal of Economics, Management and Accounting 26 (2), 457-473.

Myers, S. C. (1984). The capital structure puzzle. The Journal of Finance, 39 (3), 575-592.

Myers, S. C., \& Majluf, N. S. (1984). Corporate financing and investment decisions when firms have information that investors do not have. Journal of Financial Economics, 13 (2), 187-221.

Ogundipe, S. E., Salawu, R. O. and Ogundipe, L. O. (2012). The determinants of corporate cash holdings in Nigeria: Evidence from general method of moments (GMM). World Academy of Science, Engineering and Technology, $6(1), 978-984$.

Omolara, C. and Asaleye, A. J. (2016). Financial sector reforms and output growth in manufacturing: Empirical evidence from Nigeria. American International Journal of Contemporary Research, 6 (3), 112-125.

Omotola, L. E. (2016). Effect of Exchange Rate Fluctuations on Manufacturing Sector Output in Nigeria, Journal of Research in Business and Management, 4 (10), 32-39.

Opler, T., Pinkowitz, L., Stulz, R., \& R. Williamson. (1999). The determinants and implications of corporate cash holdings. Journal of Financial Economics, 52 (1), 3-46. 
Ozigbo, N.C (2018) How Big Data Technology is Changing the Landscape Equation for Business Performance in the $21^{\text {st }}$ Century, International Journal of Social Sciences and Humanities, Invention, 5(4), April.

Ozkan, A., \& Ozkan, N. (2004). Corporate cash holdings: An empirical investigation of UK companies. Journal of Banking \& Finance, 28 (9), 2103-2134.

Prenker, T. \& Kuck, J. (2009). The determinants of corporate cash holdings, Unpublished MSc Thesis, Lunds University.

Shabbir, M., Hashmi, S. H. \& Chaudhary, G. M. (2016). Determinants of corporate cash holdings in Pakistan. International Journal of Organizational Leadership, 5 (2), 50-62.

Simon-Oke, O. O. \& Aribisala. S. E. (2010). Exchange rate deregulation and industrial performance: An assessment (1975 - 2006), African Research Review, 4 (2), 236-251.

Sohani, I. (2012). Manufacturing firms' cash holding determinants: evidence from Bangladesh. International Journal of Business and Management, 7 (6), 172-184.

Sookim, C., Mauer, D. C. \& Sherman, A. E. (1999). The determinants of corporate liquidity: Theory and evidence. Journal of Financial and Quantitative Analysis, 33, 335 - 359.

Subramaniam, V., Tang, T.T., Yue, H., \& Zhou, X. (2011). Firm structure and corporate cash* holdings. Journal of Corporate Finance, 17, 759-773.

Thi, D., Nhun, T. \& Ha, P. (2016). Cash holding, state ownership and firm value: The case of Vietnam. International Journal of Economics and Financial Issues, 6(S6) 110-114.

Umrya, M. A. \& Diantimala, Y. (2018). The determinants of cash holdings companies in Indonesia. Journal of Accounting, Finance and Auditing Studies, 4 (4), 173-184.

Uremadu, S. O., Egbide, B. C. \& Enyi, P. E. (2012). Working capital management, liquidity and corporate profitability among quoted firms in Nigeria: Evidence from the productive sector. International Journal of Academic Research in Accounting, Finance and Management Sciences, 2 (1), 80-97.

Xiao, S. \& Zhao, S. (2014) How do agency problems affect firm value? Evidence from China, The European Journal of Finance, 20(7-9), 803-828. 